\title{
Isolation of Iron Bacteria from Washing Sludge Filters Kolda (Senegal) Water Treatment Station and Study of the Kinetics of Biological Degradation of the Iron (II)
}

\author{
Mamadou Faye ${ }^{1,2}$, Falilou Mbacké Sambe1,2, Modou Dieng2,3, Alpha Ousmane Touré1,2, \\ Matar Faye ${ }^{2,3}$, Codou Guèye Mar Diop ${ }^{1,2}$ \\ ${ }^{1}$ Laboratory of Electrochemistry and Membrane Processes (LEMP), Ecole Supérieure Polytechnique (ESP), Dakar-Fann, Senegal \\ ${ }^{2}$ Cheikh Anta Diop University of Dakar (UCAD), Dakar-Fann, Senegal \\ ${ }^{3}$ Microbiology Laboratory of the Department of Chemical Engineering and Applied Biology (ESP), Dakar-Fann, Senegal \\ Email: fayeespgc@gmail.com
}

How to cite this paper: Faye, M., Sambe, F.M., Dieng, M., Touré, A.O., Faye, M., Diop, C.G.M. (2019) Isolation of Iron Bacteria from Washing Sludge Filters Kolda (Senegal) Water Treatment Station and Study of the Kinetics of Biological Degradation of the Iron (II). Open Journal of Metal, 9, 19-32.

https://doi.org/10.4236/ojmetal.2019.93003

Received: September 13, 2019

Accepted: September 27, 2019

Published: September 30, 2019

Copyright $\odot 2019$ by author(s) and Scientific Research Publishing Inc. This work is licensed under the Creative Commons Attribution International License (CC BY 4.0).

http://creativecommons.org/licenses/by/4.0/

\begin{abstract}
In the present work, the treatment of synthetic waters doped with iron (II) has been studied. The treatment mechanism used in this study is the biological oxidation which consists, in test tubes, of bringing bacteria isolated on Petri dishes into contact with water containing divalent iron (II). These de-ironing bacteria (non-specific bacteria) are used to carry out laboratory biological oxidation experiments on iron (II) under different $\mathrm{pH}$ conditions $(\mathrm{pH}=3.4-3.6, \mathrm{pH}=7.3-7.5$ and $\mathrm{pH}=9.8-10)$ and variable concentration of iron (II). Biological treatment trials included different concentrations of iron during time intervals of a day. Examination of the elimination kinetics of Iron (II) indicates a removal rate of $59.453 \%$ for an initial iron concentration in the synthetic solution of $1 \mathrm{mg} \cdot \mathrm{L}^{-1}$ at basic $\mathrm{pH}(\mathrm{pH}=9.8-10)$. Therefore, the degradation of divalent iron by this method seems to be quite effective, but it should be noted that biological nitrification is impaired by the presence of high iron concentrations above $5 \mathrm{mg} \cdot \mathrm{L}^{-1}$.
\end{abstract}

\section{Keywords}

Biodegradation, Bacteria, Washing Mud, Iron, Kinetics, Efficiency

\section{Introduction}

Iron is one of the most abundant metals in the earth's crust and is generally associated with manganese [1]. Dissolved iron concentrations in anaerobic 
groundwater may exceed levels of the order of $10 \mathrm{mg} \cdot \mathrm{L}^{-1}$, but the usual iron concentrations are between 0.02 and $10 \mathrm{mg} \cdot \mathrm{L}^{-1}$ [2]. When exposed to oxygen, the iron can form insoluble products, mainly in the form $\mathrm{FeCO}_{3}, \mathrm{Fe}(\mathrm{OH})_{2}$ or $\mathrm{Fe}(\mathrm{OH})_{3}$. Iron oxides are highly insoluble products with a brownish color [3]. This can lead to undesirable color problems in groundwater for drinking water [4]. Therefore, the excessive presence of iron in drinking water and organisms such as the World Health Organization (WHO), the European Commission, USEPA (United States), and Canada should be avoided Health and Welfare Canada has established a maximum level of iron contamination of $0.3 \mathrm{mg} \cdot \mathrm{L}^{-1}$ [5]. The removal of dissolved iron $\left(\mathrm{Fe}^{\mathrm{II}}\right)$ from groundwater is generally achieved by oxidation, precipitation and sand filtration for the separation of oxidized insoluble products [1]. The chemical oxidation of iron dissolved by oxygen can be described by the following general equation [6]

$$
-\frac{\mathrm{d}[\mathrm{Fe}(\mathrm{II})]}{\mathrm{d} t}=K_{0}[\mathrm{Fe}(\mathrm{II})]+K_{1}[\mathrm{Fe}(\mathrm{II})]\left[\mathrm{Fe}(\mathrm{OH})_{x}\right]
$$

This expression implies that a homogeneous oxidation of iron can be accompanied by a heterogeneous auto-catalytic action, in the presence of the existing Fe solid phase [1]. However, heterogeneous auto-catalytic oxidation is more important than the homogeneity of the oxidation processes, in drinking water treatment units. Iron can be removed by aeration and precipitation or by the use of oxidants [7]. It is for these reasons that chemical oxidation is generally required to achieve iron precipitation within reasonable time and at $\mathrm{pH}$ values common to water practice, i.e. between 6 and 8. It is well established that $\mathrm{KMnO}_{4}$ and $\mathrm{ClO}_{2}$ are effective oxidants for dissolving iron in a wide range of variable $\mathrm{pH}$ values [8]. However, in water treatment processes, the use of chemical reagents should be minimized, not only because of the increased operational costs of applied treatment methods, but also because of the secondary impacts that may result from formation of residues and by-products [8].

For these reasons, the biological oxidation of iron has been considered as a viable alternative to groundwater treatment. However, there is little information to date, probably because the problem of iron contamination is less frequent and also because the process involved is considered more complex than in the case of the biological oxidation of iron [9]. The biological oxidation of $\mathrm{Fe}^{\mathrm{II}}$ is generally carried out by microorganisms [10]. In particular, the oxidation of iron can be carried out by species belonging to several types such as Leptothrix, Crenothrix, Siderocapsa Gallionella, etc. [10]. The bacteria responsible for this process seem to be bacteria without risk to the environment. These bacteria are able, thanks to the enzymes and biopolymers they develop, to oxidize iron biologically by catalyzing the oxidation of the divalent metal by dissolved oxygen, even in low concentrations, and by fixing it on their cell membranes, their sheaths, their peduncles. The precipitates formed are then strongly adherent to bacterial polymers.

In the present study, the biological oxidation of iron by bacteria isolated on a petri dish was studied during the treatment of iron-doped water using test tubes. 
The kinetics of the bacterial oxidation of iron were examined and the results were compared with the respective kinetics of the oxidation of bacterial iron as well as with the values obtained in the literature concerning abiotic oxidation. So far, most work related to bacterial oxidation of iron has been focused on batch investigations or under natural conditions [11], while detailed information on the products of biological oxidation of iron has not been reported for the case. Ongoing treatment of groundwater, but only for groundwater treatment plants in situ [12].

The main objective of this study is to study the biological degradation capacity of the iron present in our sample by isolated microorganisms and to determine the kinetic model that describes our experimental results. These results obtained will make it possible to calculate the effectiveness of this biological elimination:

$$
E(\%)=\frac{C_{i}-C_{f}}{C_{i}} \times 100
$$

\section{Materials and Methods}

\subsection{Presentation of the Sludge Sampling Area}

The Kolda region is located $484 \mathrm{~km}$ from the capital of Senegal (Dakar region) by The Gambia. It lies between $12^{\circ} 20$ and $1^{\circ} 40$ north latitude and $13^{\circ}$ and $16^{\circ}$ west longitude. It covers an area of $13,721 \mathrm{~km}^{2}$ or $7 \%$ of the national territory. It is limited to the North by the Gambia, to the East by the Tambacounda region, to the west by the Sedhiou region and to the South by Guinea Bissau and Guinea Conakry [13]. In addition, rainwater feeds the surface water of Continental Terminal, Miocene (50 and $150 \mathrm{~m}$ depth) and Quaternary. The Maestrichtian can be reached within $160 \mathrm{~m}$ in the south center and south-east of the region [14]. The quality of the water is good, nevertheless with contents of heavy metals including iron which exceed 10 times the norms of potability. Sampling was carried out at the de-ironing station installed in the city.

\subsection{Sampling Methodology}

Our choice is justified by the fact that the groundwater of this zone is quite loaded with iron and manganese. The sludge was collected at the Kolda water treatment plant. This sludge comes to us precisely from the filtration bed of the ironing unit. The sludge was put in plastic bags. These were kept cool in a cooler at about $4^{\circ} \mathrm{C}$ (Figure 1 ).

\subsection{Methodologies and Materials Used for Dosages}

The sludge was extracted at the bottom of the filters. Samples were taken using a sterile spatula at a depth of $40 \mathrm{~cm}$. For each sample, $100 \mathrm{~g}$ of sludge taken are put in sterile plastic bags. Mud samples are kept cool $\left(4^{\circ} \mathrm{C}\right)$. For seeding and isolation, we use Petri dishes (Figure 2) containing nutrient agar (GN).

In order to be in the calibration range, $\left[\mathrm{Fe}^{2+}\right]_{0}<6 \mathrm{mg} \cdot \mathrm{L}^{-1}$, we prepared a stock solution of $4 \times 10^{-5} \mathrm{M}$ iron sulfate $\left(\mathrm{FeSO}_{4}\right)$ dissolved in distilled water. In $100 \mathrm{ml}$ 


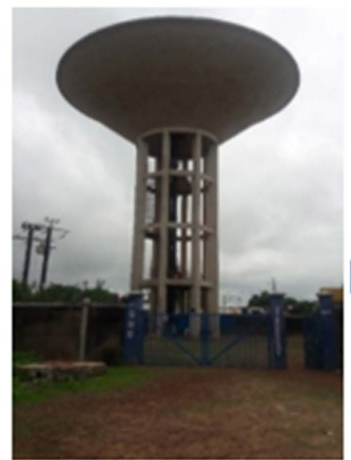

(a)

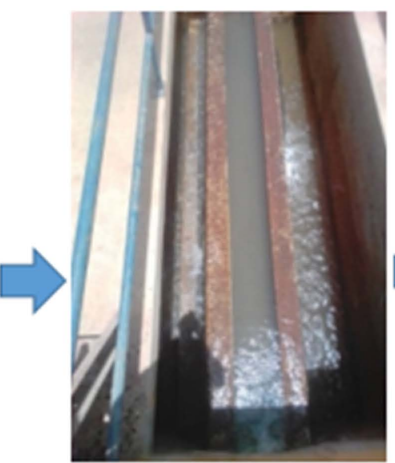

(b)

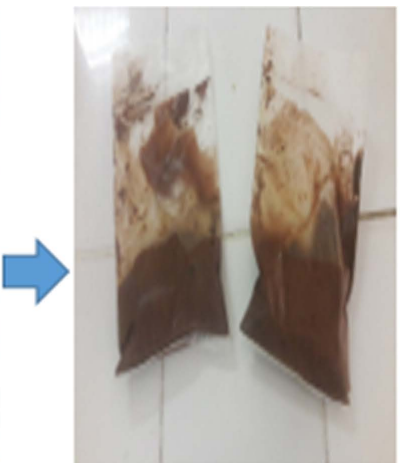

(c)

Figure 1. (a) Kolda (Senegal) Station; (b) bed iron filtration; (c) washing sludge.

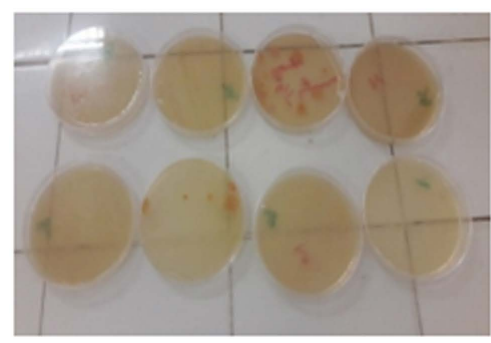

(a)

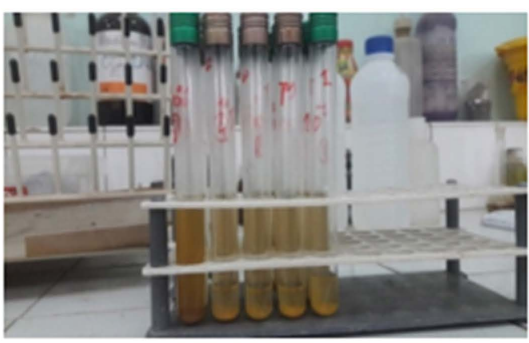

(b)

Figure 2. (a) Isolation of bacteria on petri dishes; (b) Test tube: contact between water doped with $\mathrm{Fe}$ (II) and bacteria.

volumetric flasks numbered from 1 to 7 , put the volumes of reagents indicated in the following table, and adjust to the mark (Table 1). After adjusting to volume, mix thoroughly and let sit for 5 to 10 minutes. In the meantime, prepare the reference and then measure the optical density at $510 \mathrm{~nm}$ from the reference solution.

\section{Results and Discussion}

The calibration curve is then obtained from the measurement of the absorbance of each standard solution (Figure 3).

The concentration of the sample taken is calculated by multiplying by 10 the concentration obtained (to take into account the dilution factor). The corresponding iron concentration is calculated from the following relation:

$$
\left[\mathrm{Fe}^{2+}\right]_{\text {Total }}=\frac{A B S-0.0577}{0.1418}
$$

\subsection{Effect of Initial Iron Concentration as a Function of $\mathrm{pH}$}

The influence of the initial iron concentration in the synthetic solution on the performance of the biological elimination of iron by microorganisms was studied for different initial iron concentrations of $1,2,3,4$ and $5 \mathrm{mg} \cdot \mathrm{L}^{-1}$. The tests were carried out at different $\mathrm{pH}(\mathrm{pH}=3.4-3.6 ; \mathrm{pH}=7.3-7.5$ and $\mathrm{pH}=9.8-$ 10 ), an operating pressure of 1.013 bar and a temperature of $2^{\circ} \mathrm{C} \pm 1^{\circ} \mathrm{C}$. 


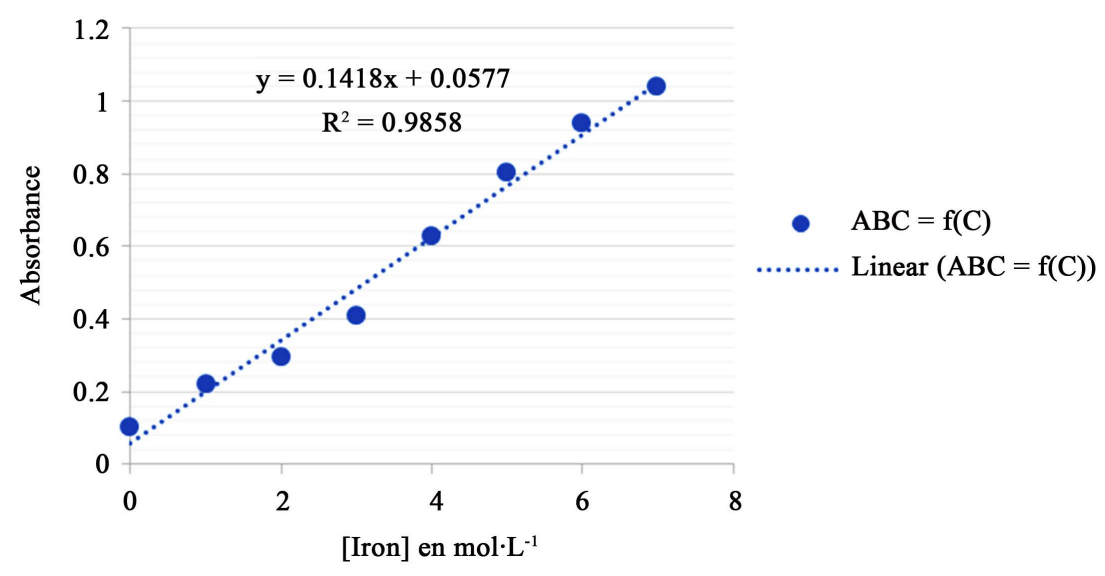

Figure 3. Calibration curve of the absorbance of the solution as a function of concentration.

Table 1. Preparation of solutions for the calibration curve.

\begin{tabular}{|c|c|c|c|c|}
\hline $\begin{array}{l}\text { Initial } \\
\text { Solution } \\
\text { (mL) }\end{array}$ & $\begin{array}{l}\text { Hydroxylammonium } \\
\text { Chloride } 10 \%(\mathrm{~mL})\end{array}$ & $\begin{array}{l}\text { Sodium } \\
\text { Acetate } \\
2 \mathrm{M}(\mathrm{mL})\end{array}$ & $\begin{array}{c}\text { Ortho-Phenanthroline } \\
0.25 \%(\mathrm{~mL})\end{array}$ & $\begin{array}{c}\text { Final } \\
\text { Concentration } \\
{\left[\mathrm{Fe}^{2+}\right]\left(\text { mole } \cdot \mathrm{L}^{-1}\right)}\end{array}$ \\
\hline 1 & 10 & 1 & 8 & $4 \times 10^{-7}$ \\
\hline 2 & 10 & 2 & 8 & $8 \times 10^{-7}$ \\
\hline 3 & 10 & 3 & 8 & $1.2 \times 10^{-6}$ \\
\hline 4 & 10 & 4 & 8 & $1.6 \times 10^{-6}$ \\
\hline 5 & 10 & 5 & 8 & $2 \times 10^{-6}$ \\
\hline 6 & 10 & 6 & 8 & $2.4 \times 10^{-6}$ \\
\hline 7 & 10 & 7 & 8 & $2.8 \times 10^{-6}$ \\
\hline
\end{tabular}

Figure 4 and Figure 5 show the influence of the initial concentration of iron as a function of time (day) for different $\mathrm{pH}$ of the solution. Figure 4 shows that for an initial concentration of $5 \mathrm{mg} \cdot \mathrm{L}^{-1}$, an instantaneous increase in iron concentration, up to $5.4 \mathrm{mg} \cdot \mathrm{L}^{-1}$, is observed after three (3) days of incubation for $\mathrm{pH}=3.4-3.6$ and $\mathrm{pH}=7.3-7.5$ solutions. We observe, then a gradual decrease to $4.83 \mathrm{mg} \cdot \mathrm{L}^{-1}$ and $4.69 \mathrm{mg} \cdot \mathrm{L}^{-1}$ after 10 days incubation respectively for $\mathrm{pH}=$ 3.4 - 3.6 solutions and $\mathrm{pH}=7.3-7.5$. On the other hand, $\mathrm{pH}=9.8-10$ we recorded an instantaneous decrease after the first days of incubation up to 4.65 $\mathrm{mg} \cdot \mathrm{L}^{-1}$ after 10 days.

Furthermore, Figure 5 shows that for an initial concentration of $4 \mathrm{mg} \cdot \mathrm{L}^{-1}$, an instantaneous increase in iron concentration is observed from the first day of incubation for the different solutions. We then observe a decrease in the concentration in the three tubes to reach $3.56 \mathrm{mg} \cdot \mathrm{L}^{-1}, 3.43 \mathrm{mg} \cdot \mathrm{L}^{-1}$ and $3.32 \mathrm{mg} \cdot \mathrm{L}^{-1}$ after 10 days of incubation respectively for the solutions of $\mathrm{pH}=3.4-3.6, \mathrm{pH}=$ $7.3-7.5$ and $\mathrm{pH}=9.8-10$. Indeed, in view of the results obtained the biological elimination of iron is more effective in the tubes with an initial concentration of $4 \mathrm{mg} \cdot \mathrm{L}^{-1}$. Because the ratio $\mathrm{C} / \mathrm{C}_{0}$ passes from 0.94 to 0.85 respectively for initial 


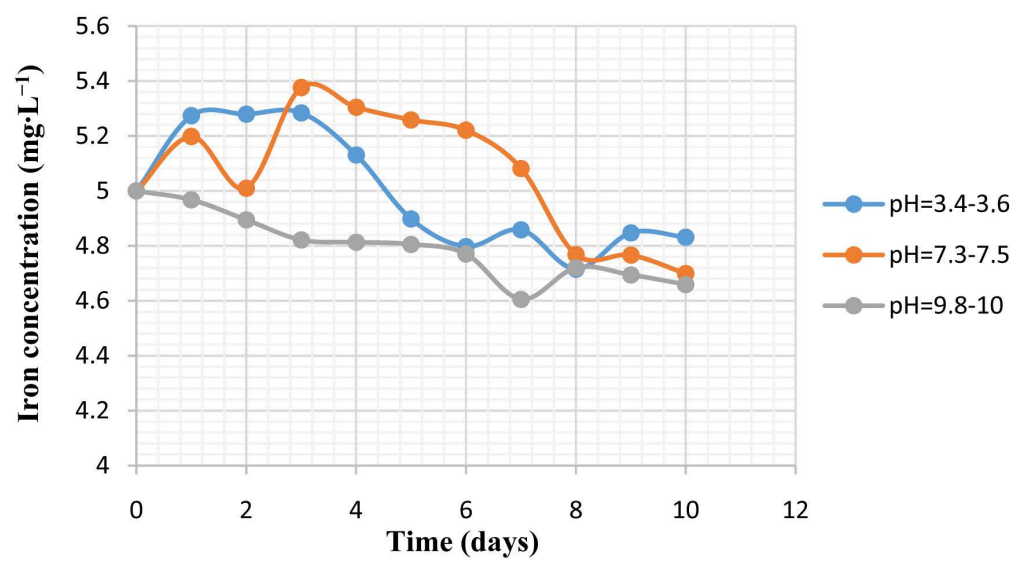

Figure 4. Kinetics of iron oxidation by microorganisms and evolution of iron concentration $\left(\left[\mathrm{Fe}^{2+}\right]_{0}=5 \mathrm{mg} \cdot \mathrm{L}^{-1}, P_{\mathrm{atm}}=1.013 \mathrm{bar}\right.$ and $\left.T=21^{\circ} \mathrm{C} \pm 1^{\circ} \mathrm{C}\right)$.

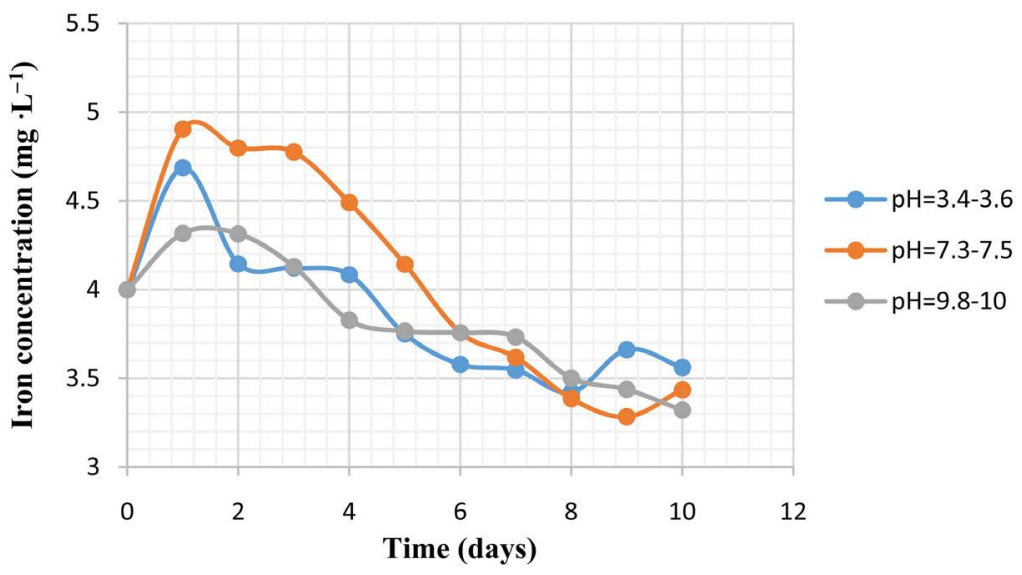

Figure 5. Kinetics of iron oxidation by microorganisms and evolution of iron concentration $\left(\left[\mathrm{Fe}^{2+}\right]_{0}=4 \mathrm{mg} \cdot \mathrm{L}^{-1}, P_{\text {atm }}=1.013\right.$ bar and $\left.T=21^{\circ} \mathrm{C} \pm 1^{\circ} \mathrm{C}\right)$.

concentrations of 5 to $4 \mathrm{mg} \cdot \mathrm{L}^{-1}$ for the same $\mathrm{pH}=7.3-7.5$. Under the same conditions, however, for a $\mathrm{pH}=3.4-3.6$, the $\mathrm{C} / \mathrm{C}_{0}$ value increases from 0.96 to 0.89 and for a $\mathrm{pH}=9.8-10$, the ratio increases from 0.93 to 0.83 . This trend is observed, with treatment rates becoming more effective for lower and lower initial concentrations and basic $\mathrm{pH}$. Therefore, the kinetics of iron removal is slow and inefficient for initial concentrations of iron $\geq 5 \mathrm{mg} \cdot \mathrm{L}^{-1}$ and acidic $\mathrm{pH}$. It should, therefore, be at basic $\mathrm{pH}$ to remove iron in the case of our study. This hypothesis could be considered for the treatment of drinking water, but it would require an increase in the costs related to the exploitation and a difficulty to manage the adjustment of the $\mathrm{pH}$ of the water except if the water is not very buffered. These microorganisms are then able to degrade the surplus of iron in the groundwater.

In order to confirm the hypothesis that the efficiency of biological treatment increases with lower iron concentrations, we also studied the influence of the initial iron concentration as a function of time (day) for different $\mathrm{pH}$ of the solution for initial iron concentrations of 1,2 and $3 \mathrm{mg} \cdot \mathrm{L}^{-1}$ materialized in Figures 6-8 below. In addition, it has been established by several authors that at high $\mathrm{pH}$ 


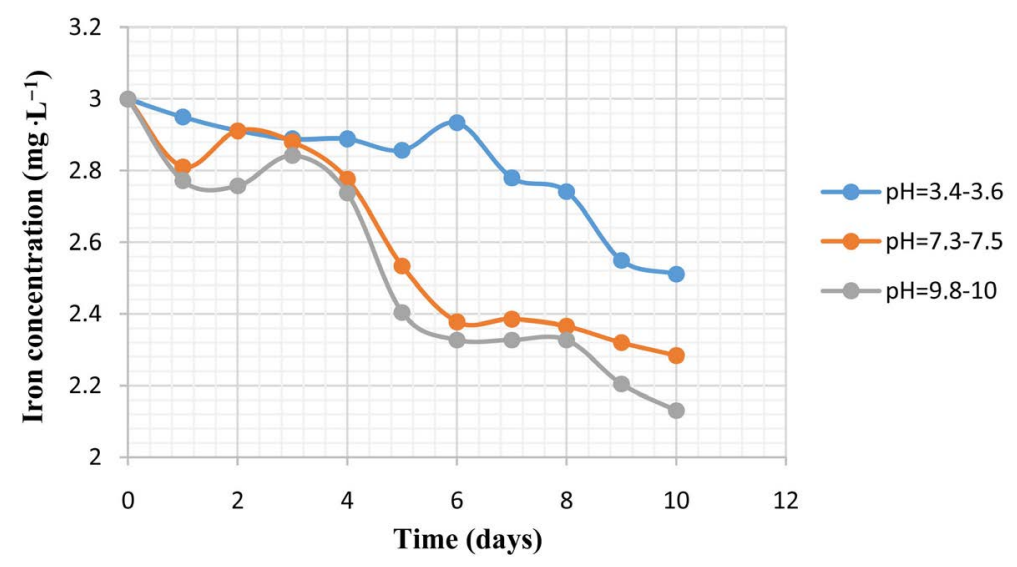

Figure 6. Kinetics of iron oxidation by microorganisms and evolution of iron concentration $\left(\left[\mathrm{Fe}^{2+}\right]_{0}=3 \mathrm{mg} \cdot \mathrm{L}^{-1}, P_{\mathrm{atm}}=1.013\right.$ bar and $\left.T=21^{\circ} \mathrm{C} \pm 1^{\circ} \mathrm{C}\right)$.

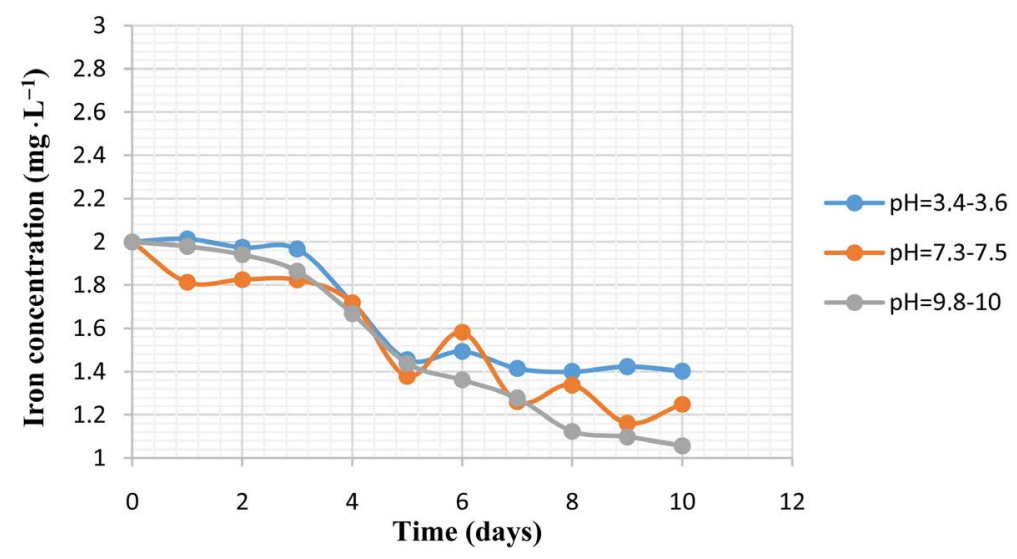

Figure 7. Kinetics of iron oxidation by microorganisms and evolution of iron concentration $\left(\left[\mathrm{Fe}^{2+}\right]_{0}=2 \mathrm{mg} \cdot \mathrm{L}^{-1}, P_{\mathrm{atm}}=1.013\right.$ bar and $\left.T=21^{\circ} \mathrm{C} \pm 1{ }^{\circ} \mathrm{C}\right)$.

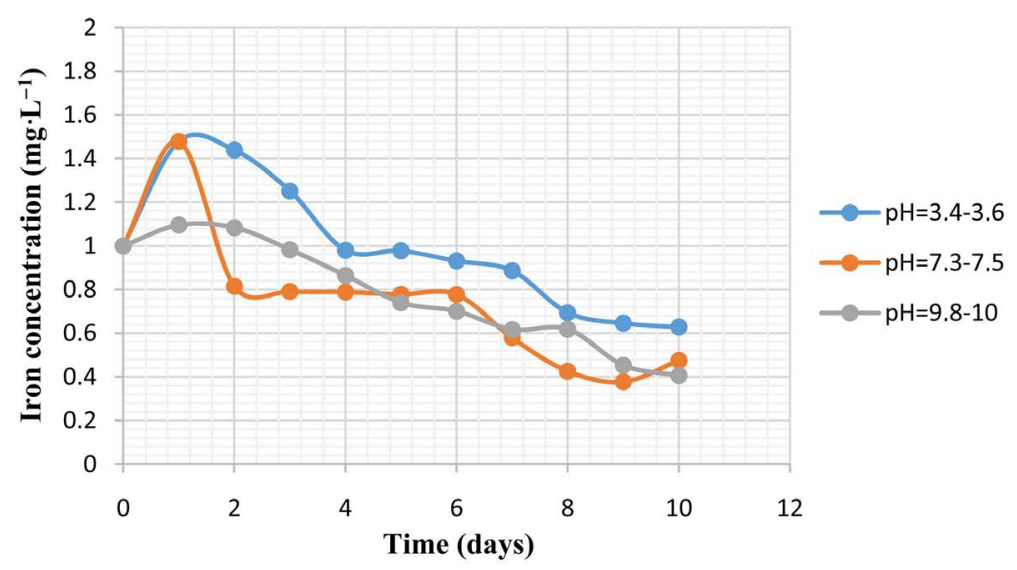

Figure 8. Kinetics of iron oxidation by microorganisms and evolution of iron concentration $\left(\left[\mathrm{Fe}^{2+}\right]_{0}=1 \mathrm{mg} \cdot \mathrm{L}^{-1}, P_{\mathrm{atm}}=1.013\right.$ bar and $\left.T=21^{\circ} \mathrm{C} \pm 1^{\circ} \mathrm{C}\right)$.

(higher than the values studied), the kinetics of biological oxidation of ferrous iron increases [15] [16] [17]. On the other hand, at high concentrations, the formation of ferric hydroxide is more pronounced (high turbidity of the solu- 
tion); which should, therefore, increase the kinetics of the oxidation reaction by the bacteria. But, we have noted at this level lower percentages of degradation. These experimental data confirm the work of some authors, that for high values of initial ferrous iron concentration, i.e. concentrations above $5 \mathrm{mg} \cdot \mathrm{L}^{-1}$, the $\mathrm{mi}$ croorganisms could become ineffective.

Figure 6 shows that for an initial concentration of $3 \mathrm{mg} \cdot \mathrm{L}^{-1}$, an instantaneous decrease in iron concentration, from the first day of incubation for the three (3) solutions of $\mathrm{pH}=3.4-3.6, \mathrm{pH}=7.3-7.5$ and $\mathrm{pH}=9.8-10$. For this initial iron concentration, we recorded $\mathrm{C} / \mathrm{C}_{0}$ values of $0.84,0.76$ and 0.71 respectively for solutions of $\mathrm{pH}=3.4-3.6, \mathrm{pH}=7.3-7.5$ and $\mathrm{pH}=9.8-10$. With regard to Figure 7 for an initial concentration of $2 \mathrm{mg} \cdot \mathrm{L}^{-1}$, we observe the same trends as in Figure 6. Indeed, an instantaneous decrease in iron concentration is noted, from the first day of incubation for the three (3) solutions of $\mathrm{pH}=3.4-3.6, \mathrm{pH}=7.3$ 7.5 and $\mathrm{pH}=9.8-10$. In addition, we recorded $\mathrm{C} / \mathrm{C}_{0}$ values of $0.70,0.62$ and 0.52 respectively for solutions of $\mathrm{pH}=3.4-3.6, \mathrm{pH}=7.3-7.5$ and $\mathrm{pH}=9.8-10$. This evolution of the kinetics of biological degradation of iron (Figure 8) is manifested in the same way for an initial concentration of $1 \mathrm{mg} \cdot \mathrm{L}^{-1}$. Moreover, we recorded higher $\mathrm{C} / \mathrm{C}_{0}$ ration values compared to higher concentrations. As a result, biological treatment becomes more effective at low initial iron concentrations and basic $\mathrm{pH}(\mathrm{pH}$ is one of the important parameters that changes filtration performance). Thus, which could relate to low concentrations, the formation of ferric hydroxide is more pronounced; which subsequently increases the kinetics of the oxidation reaction.

\subsection{Linear Regression Analysis of the Biological Elimination of $\mathrm{Fe}^{\mathrm{II}}$}

Experiments performed by adding $\mathrm{Fe}^{\mathrm{II}}$ to the distilled water stream, at different initial iron concentrations described above, were expressed as $\log \left([\mathrm{Fe}(\mathrm{II})]_{\mathrm{t}} /[\mathrm{Fe}\right.$ (II) $]_{0}$ ) as a function of time (contact time with the empty bed) (Figures 9-13).

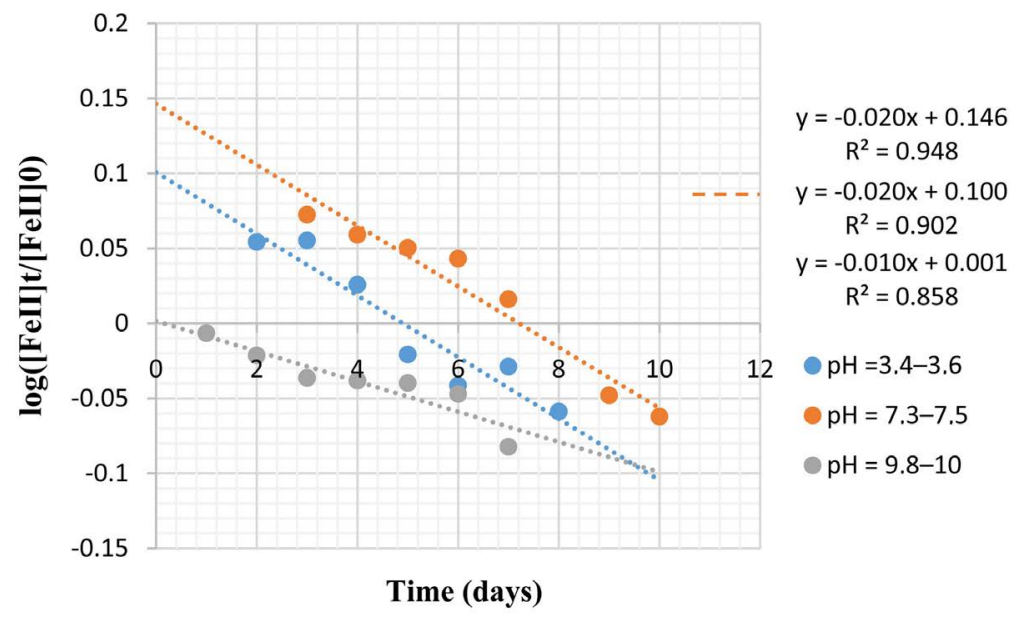

Figure 9. Linear regression analysis of the biological elimination of Fe (II) versus treatment time for an initial $\mathrm{Fe}$ (II) concentration of $5 \mathrm{mg} \cdot \mathrm{L}^{-1}$. 


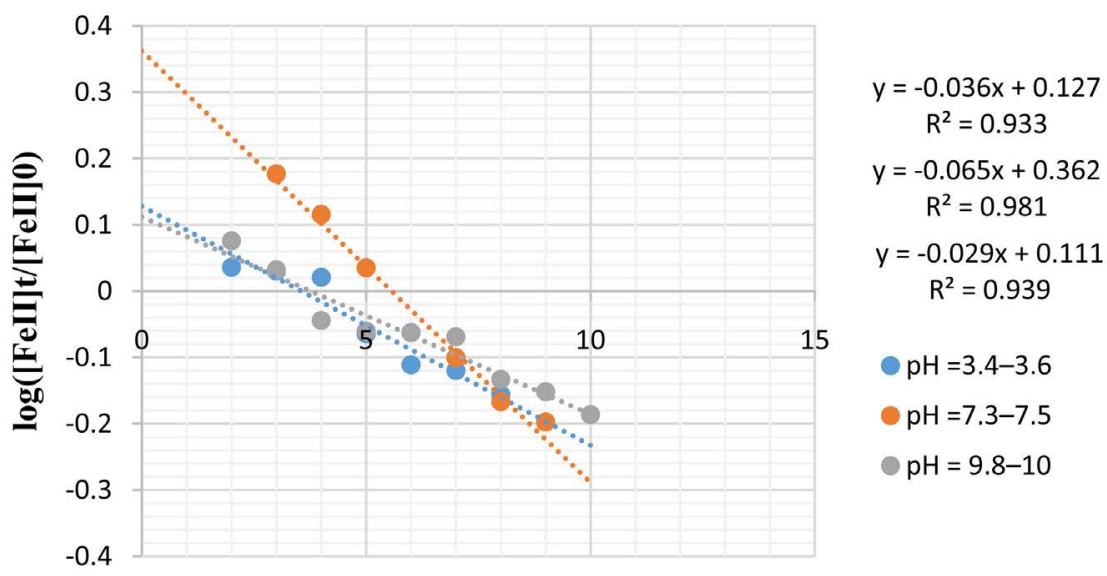

Time (days)

Figure 10. Linear regression analysis of the biological elimination of Fe (II) versus treatment time for an initial Fe (II) concentration of $4 \mathrm{mg} \cdot \mathrm{L}^{-1}$.

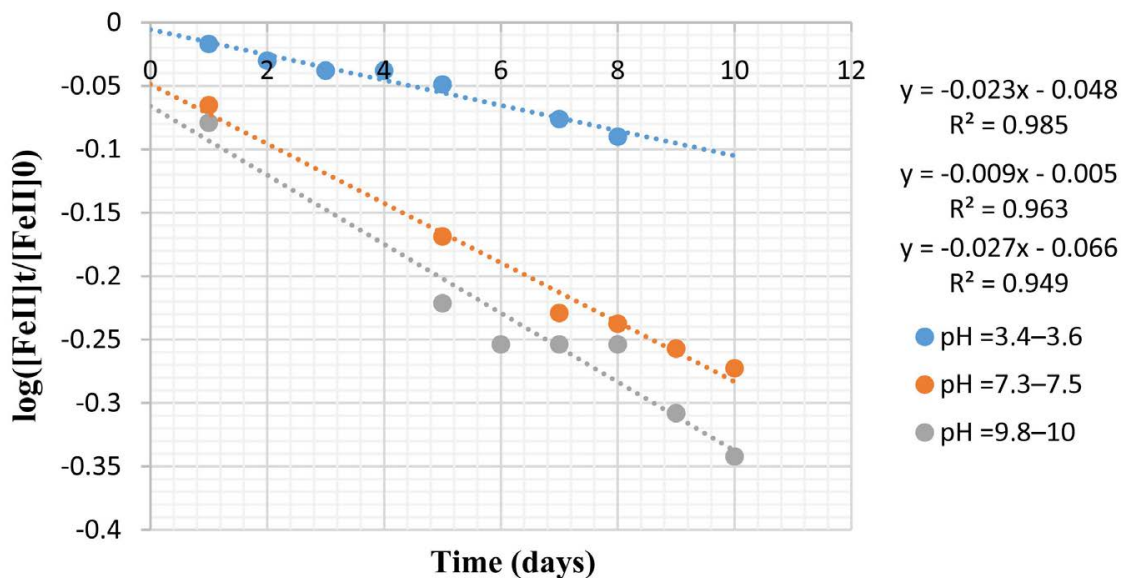

Figure 11. Linear regression analysis of the biological elimination of Fe (II) versus treatment time for an initial Fe (II) concentration of $3 \mathrm{mg} \cdot \mathrm{L}^{-1}$.

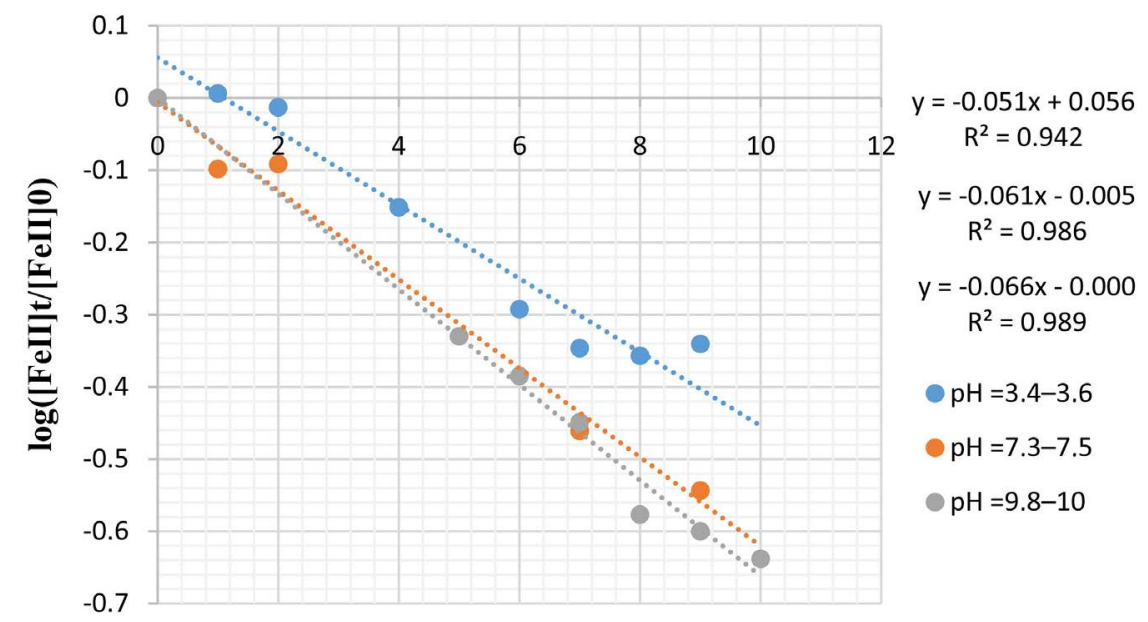

Time (days)

Figure 12. Linear regression analysis of the biological elimination of Fe (II) versus treatment time for an initial Fe (II) concentration of $2 \mathrm{mg} \cdot \mathrm{L}^{-1}$. 


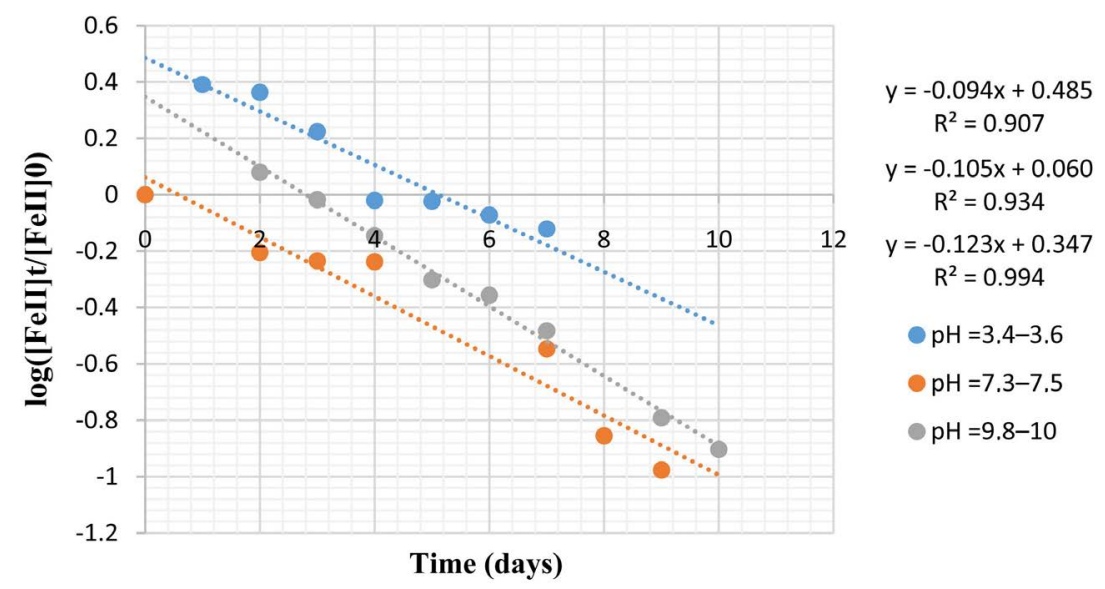

Figure 13. Linear regression analysis of the biological elimination of Fe (II) versus treatment time for an initial Fe (II) concentration of $1 \mathrm{mg} \cdot \mathrm{L}^{-1}$.

The linearity of the curves revealed that iron oxidation also followed a first-order kinetic rate, given by the following equation:

$$
-\frac{\mathrm{d}[\mathrm{Fe}(\mathrm{II})]}{\mathrm{d} t}=k[\mathrm{Fe}(\mathrm{II})]
$$

For a $\mathrm{pH}$ and initial concentration of variable iron, the kinetic constants found by applying the kinetic model above to our experimental results are equal:

- Solution 1: $C_{0}=5 \mathrm{mg} \cdot \mathrm{L}^{-1}\left(k=0.0203 \mathrm{mn}^{-1}\right.$ for a $\mathrm{pH}=3.4-3.6 ; k=0,0205$ $\mathrm{mn}^{-1}$ for a $\mathrm{pH}=7.3-7.5$ and $k=0.0101 \mathrm{mn}^{-1}$ for a $\mathrm{pH}=9.8-10$ );

- Solution 2: $C_{0}=4 \mathrm{mg} \cdot \mathrm{L}^{-1}\left(k=0.036 \mathrm{mn}^{-1}\right.$ for a $\mathrm{pH}=3.4-3.6 ; k=0.0651$ $\mathrm{mn}^{-1}$ for a $\mathrm{pH}=7.3-7.5$ and $\left.k=0.0297 \mathrm{mn}^{-1} \mathrm{pH}=9.8-10\right)$;

- Solution 3: $C_{0}=3 \mathrm{mg} \cdot \mathrm{L}^{-1}\left(k=0.0234 \mathrm{mn}^{-1}\right.$ for a $\mathrm{pH}=3.4-3.6 ; k=0.0099$ $\mathrm{mn}^{-1}$ for a $\mathrm{pH}=7.3-7.5$ and $k=0.0272 \mathrm{mn}^{-1}$ for a $\left.\mathrm{pH}=9.8-10\right)$;

- Solution 4: $C_{0}=2 \mathrm{mg} \cdot \mathrm{L}^{-1}\left(k=0.051 \mathrm{mn}^{-1}\right.$ for a $\mathrm{pH}=3.4-3.6 ; k=0.0605$ $\mathrm{mn}^{-1}$ for a $\mathrm{pH}=7.3-7.5$ et $k=0.0662 \mathrm{mn}^{-1} \mathrm{pH}=9.8-10$ );

- Solution 5: $C_{0}=1 \mathrm{mg} \cdot \mathrm{L}^{-1}\left(k=0.0949 \mathrm{mn}^{-1}\right.$ for a $\mathrm{pH}=3.4-3.6 ; k=0.1055$ $\mathrm{mn}^{-1}$ for a $\mathrm{pH}=7.3-7.5$ and $k=0.1238 \mathrm{mn}^{-1}$ for a $\left.\mathrm{pH}=9.8-10\right)$.

These results clearly show that the biological oxidation of iron is a very slow reaction under the specified experimental conditions of synthetic waters doped with iron. In fact, we observed higher kinetic constant values at $C_{0}=1 \mathrm{mg} \cdot \mathrm{L}^{-1}(k$ $=0.0949 \mathrm{mn}^{-1}$ for a $\mathrm{pH}=3.4-3.6, k=0.1055 \mathrm{mn}^{-1}$ for a $\mathrm{pH}=7.3-7.5$ and $k=$ $\left.0.1238 \mathrm{~min}^{-1} \mathrm{pH}=9.8-10\right)$. Therefore, it is under these conditions that the reaction of biological degradation of iron (II) by ferrobacteria is faster compared to others. Then this result confirms the conclusion that was emitted during the tests of the study of the kinetics of iron oxidation by microorganisms at different $\mathrm{pH}$ and concentrations (the biological treatment of iron becomes more efficient for initial iron concentrations low and basic $\mathrm{pH}$ ). This can also be indicated by the calculated half-life constant of the biological oxidation of iron, which was found to be 9 days at $C_{0}=1 \mathrm{mg} \cdot \mathrm{L}^{-1}$ and $\mathrm{pH}=9.8-10$. This is the smallest half-life time from all experiments of different experimental conditions. 
In many works, to increase iron degradation yields the authors coupled the biological oxidation of iron to that of the physic-chemical (Pourbaix diagram). This was found in studies of [18]. The comparison between the removal of Fe $\mathrm{F}^{\mathrm{II}}$ biological and physic-chemical in a similar processing unit showed that the removal of iron by the chemically accounted for almost $50 \%$ of the total iron removal. However, these values are consistent with the work of [19] concerning the biological iron removal of groundwater.

\subsection{Percentage Evaluation of Biological Treatment}

The results of this experiment are used to calculate the percentage of iron removed by the bacteria. The kinetics achieved previously used to calculate the percentage of iron removed after 10 days of contact time (incubation) with the isolated microorganisms in Petri dishes. Table 2 contains all the biological treatment rates.

Looking at the percentage values of eliminated iron obtained during the kinetic tests, it should be noted that we recorded low iron abatement rates for high initial concentrations, especially at relatively acidic $\mathrm{pH}$. The results (Table 2) show that the elimination percentages of the most efficient iron are obtained in the tube $5-C=1 \mathrm{mg} \cdot \mathrm{L}^{-1}$ (Tube $5^{\mathrm{a}}-\mathrm{pH} 3.4-3.6-\mathrm{Fe}^{\mathrm{II}}=37.211 \%$; Tube $5^{\mathrm{b}}-\mathrm{pH}=$ $7.3-7.5-\% \mathrm{Fe}^{\mathrm{II}}=52.592$, Tube $\left.5^{\mathrm{c}}-\mathrm{pH}=9.8-10-\% \mathrm{Fe}^{\mathrm{II}}=59.453\right)$. In conclusion, the iron contents vary according to the $\mathrm{pH}$ of the culture medium, these results are significant but more need to be optimized because the remaining iron contents (after 10 days of incubation) are well above the norm WHO recommendation in drinking water.

Table 2. Percent removal of iron from microorganism-doped water after 10 days of contact time (incubation).

\begin{tabular}{|c|c|c|c|}
\hline \multirow{2}{*}{$\begin{array}{c}\text { TUBE NUMBER } \\
\mathrm{pH}\end{array}$} & \multicolumn{3}{|c|}{ TUBE $1-C=5 \mathrm{mg} \cdot \mathrm{L}^{-1}$} \\
\hline & $\mathrm{pH}=3.4-3.6$ & $\mathrm{pH}=7.3-7.5$ & $\mathrm{pH}=9.8-10$ \\
\hline$\%$ of elimination & 3.365 & 6.012 & 6.809 \\
\hline TUBE NUMBER & \multicolumn{3}{|c|}{ TUBE $2-\mathrm{C}=4 \mathrm{mg} \cdot \mathrm{L}^{-1}$} \\
\hline $\mathrm{pH}$ & $\mathrm{pH}=3.4-3.6$ & $\mathrm{pH}=7.3-7.5$ & $\mathrm{pH}=9.8-10$ \\
\hline$\%$ of elimination & 10.975 & 14.111 & 16.987 \\
\hline TUBE NUMBER & \multicolumn{3}{|c|}{ TUBE $3-\mathrm{C}=3 \mathrm{mg} \cdot \mathrm{L}^{-1}$} \\
\hline $\mathrm{pH}$ & $\mathrm{pH}=3.4-3.6$ & $\mathrm{pH}=7.3-7.5$ & $\mathrm{pH}=9.8-10$ \\
\hline$\%$ of elimination & 16.294 & 23.863 & 28.977 \\
\hline TUBE NUMBER & \multicolumn{3}{|c|}{ TUBE $4-C=1 \mathrm{mg} \cdot \mathrm{L}^{-1}$} \\
\hline $\mathrm{pH}$ & $\mathrm{pH}=3.4-3.6$ & $\mathrm{pH}=7.3-7.5$ & $\mathrm{pH}=9.8-10$ \\
\hline$\%$ of elimination & 29.904 & 37.575 & 47.164 \\
\hline TUBE NUMBER & \multicolumn{3}{|c|}{ TUBE $5-\mathrm{C}=1 \mathrm{mg} \cdot \mathrm{L}^{-1}$} \\
\hline $\mathrm{pH}$ & $\mathrm{pH}=3.4-3.6$ & $\mathrm{pH}=7.3-7.5$ & $\mathrm{pH}=9.8-10$ \\
\hline$\%$ of elimination & 37.211 & 52.592 & 59.453 \\
\hline
\end{tabular}


Overall the view of our results, the decrease in iron content could be explained by the fact that certain bacteria (iron bacteria) develop the ability to use iron (III) as electron acceptor under anaerobic conditions. There is, therefore, oxidation of iron (II) by the microorganisms and later by the oxygen thus causing the formation of precipitate in the form of iron (III). Bacteria yet are able to interact indirectly with the iron through the production of metabolites. Some bacteria use iron (II) as an electron donor. Microbiologists have discovered that some bacteria are able to capture and immobilize iron. The bacteria responsible for this process seem to be bacteria without risk to the environment. These bacteria are able, thanks to the enzymes and biopolymers they develop, to oxidize iron biologically by catalyzing the oxidation of the divalent metal by dissolved oxygen, even in low concentrations, and by fixing it on their cell membranes, their sheaths, their peduncles, etc. The precipitates formed are then highly adherent to bacterial polymers. Increasing the iron content observed in some tubes could be explained by two things:

- First, this increase in iron concentration over time could be due to cell death leading to reduction in the number of bacteria able to capture iron, in addition, it would release iron in the medium;

- Also, he might have contamination at our manipulations thus inhibiting the activity of iron bacteria (iron bacteria) or during the operation of determining iron by ortho-phenanthroline method.

\section{Conclusions}

In this paper, the results of the study of the kinetics of biological iron removal of reconstituted synthetic waters and the evaluation of removal rates from biological oxidation were examined. Biological iron removal was found to follow a first-order reaction rate. Reaction rates are quite slow, but nevertheless the treatment process is quite economical and environmentally friendly because the additional use of chemical reagents is not necessary during the treatment period.

The study showed that the performance in terms of efficiency depends strongly on the initial concentration of iron. Indeed, we recorded higher abatement rates for low concentrations (Table 2). Regarding the influence of operating conditions including $\mathrm{pH}$, it also shows a very significant effect on the iron removal rate. In other words, optimal efficiency is obtained at $\mathrm{pH}=9.8$ to 10 basic and $\mathrm{C}_{0}=1 \mathrm{mg} \cdot \mathrm{L}^{-1}$. The results obtained are promising in terms of elimination rates from biological oxidation to comply with WHO recommendations.

\section{Conflicts of Interest}

The authors declare no conflicts of interest regarding the publication of this paper.

\section{References}

[1] Charles, P. (2008) Elimination catalytique du fer et du manganèse pour la production 
d'eau potable. Etude financée par l'Agence de l'Eau Seine Normandie, Rapport Final SUEZ Environnement, Octobre.

[2] Chatain, V. (2004) Caractérisation de la mobilisation potentielle de l'arsenic et d'autres constituants inorganiques présents dans les sols issus d'un site minier aurifère. Thèse, Institut National des Sciences Appliquées de Lyon.

[3] Du, X., Liu, G., Qu, F., Li, K., Shao, S., Li, G. and Liang, H. (2017) Removal of Iron, Manganese and Ammonia from Groundwater Using a PAC-MBR System: The Anti-Pollution Ability, Microbial Population and Membrane Fouling. Desalination, 403, 97-106. https://doi.org/10.1016/j.desal.2016.03.002

[4] Kouassi, M.A., Okaingni, J.C., Baka, D., Lasm, T., Kouame, F.K. and Biemi, J. (2012) Application des méthodes statistiques et géostatistiques à l'étude de la conductivité électrique des eaux souterraines de la région du N'zi-Comoé (Centre-Est de la Côte d'Ivoire). International Journal of Biological and Chemical Sciences, 6, 897-912. https://doi.org/10.4314/ijbcs.v6i2.31

[5] Chen, P., Bornhorst, J. and Aschner, M. (2018) Manganese Metabolism in Humans. Frontiers in Bioscience (Landmark Edition), 23, 1655-1679. https://doi.org/10.2741/4665

[6] Drits, V. and Manceau, A. (2000) A Model for the Mechanism of $\mathrm{Fe}^{3+}$ to $\mathrm{Fe}^{2+} \mathrm{Re}$ duction in Dioctahedral Smectites. Clays and Clay Minerals, 48, 185-195. https://doi.org/10.1346/CCMN.2000.0480204

[7] Jean Rodier, B.L., Merlet, N., et al. (2009) Analyse de l'eau. Dunod, Paris, 1579.

[8] Homoky, W., Hembury, D., Hepburn, L., Mills, R., Statham, P., Fones, G. and Palmer, M. (2011) Iron and Manganese Diagenesis in Deep Sea Volcanogenic Sediments and the Origins of Pore Water Colloids. Geochimica et Cosmochimica Acta, 75, 5032-5048. https://doi.org/10.1016/j.gca.2011.06.019

[9] Dégremont (2005) Les eaux eaux potable-Mémento technique de l'eau: Tome 2. Lavoisier SAS (Éditeur)—Lexique technique de l'eau, Paris, $10^{\mathrm{e}}$ édition, $785 \mathrm{p}$.

[10] De Pontual, L. (2017) Fer et prédisposition aux infections. Archives de Pédiatrie, 24, 5S14-15S17. https://doi.org/10.1016/S0929-693X(17)24004-4

[11] Pacini, V.A., Ingallinella, A.M. and Sanguinetti, G. (2005) Removal of Iron and Manganese Using Biological Roughing up Flow Filtration Technology. Water Research, 39, 4463-4475. https://doi.org/10.1016/j.watres.2005.08.027

[12] El Araby, R., Hawash, S. and El Diwani, G. (2009) Treatment of Iron and Manganese in Simulated Groundwater via Ozone Technology. Desalination, 249, 1345-1349. https://doi.org/10.1016/j.desal.2009.05.006

[13] Dieye, P.N. (2003) Comportements des acteurs et performances de la filière lait périurbain de Kolda (Sénégal). Institut agronomique méditerranéen.

[14] Pontié, M., Rumeau, M., Ndiaye, M. and Diop, C.M. (1996) Sur le problème de la fluorose au Sénégal: Bilan des connaissances et présentation d'une nouvelle. Cahiers Santé, 6, 27-36.

[15] Hamdeni, R.F. (2017) Performances du système hybride précipitation/microfiltration et de la nanofitration dans l'élimination du fer pour la potabilisation de l'eau. Université de Lyon. Document-thèse. https://tel.archives-ouvertes.fr/tel-01810978

[16] Elhussien, M. (2017) Removal of Iron (II) from Aqueous Solution Using Activated Carbon Derived from Pods of Acacia Nilotica Var Astringens (Sunt Tree) by Chemical Activation with $\mathrm{ZnCl}_{2}$. American Journal of Physical Chemistry, 6, 59-69. https://doi.org/10.11648/j.ajpc.20170604.12 
[17] Tufekci, N. and Sarikaya, H.Z. (1998) Influence of Ageing on the Catalytic Activity of Ferric Sludge for Oxidation of Fe (II). Water Science and Technology, 38, 129-137. https://doi.org/10.2166/wst.1998.0245

[18] Katsoyiannis, I. and Zouboulis, A. (2004) Application of Biological Processes for the Removal of Arsenic from Groundwaters. Water Research, 38, 17-26. https://doi.org/10.1016/j.watres.2003.09.011

[19] Sogaard, E.G., Medenwaldt, R. and Abraham-Peskir, J.V. (2000) Conditions and Rates of Biotic and Abiotic Iron Precipitation in Selected Danish Freshwater Plants and Microscopic Analysis of Precipitate Morphology. Water Research, 34, 2675-2682. https://doi.org/10.1016/S0043-1354(00)00002-6 